\title{
A Study of Determinants of Lecturer Performance: The Islamic Universities in Makassar City Case
}

\author{
Amiruddin, Mahfudnurnajamuddin, Mapparenta, Zainal Arifin, Budiandriani
}

\section{ABSTRACT}

This research aims to explore the determinants of lecturer performance at Islamic Universities in Makassar City using 327 foundation lecturers or civil servants. Data testing was carried out using AMOS (Analysis of Moment Structures). The results of this study provide evidence that leadership directly has a negative and insignificant effect on job satisfaction. Motivation has a negative and insignificant effect on lecturer performance, similar results were obtained in the indirect effect test, that work motivation has a negative and insignificant effect on lecturer performance through job satisfaction. The two-stage test results provide evidence that work motivation has a negative and insignificant effect on lecturer performance.

Keywords: Competence, job satisfaction, leadership, lecturer performance, motivation.

\author{
Submitted : March 6, 2021 \\ Published : March 28, 2021 \\ ISSN: $2507-1076$ \\ DOI: $10.24018 / \mathrm{ejbmr} .2021 .6 .2 .801$ \\ Amiruddin * \\ STIM LPI Makassar, Indonesia. \\ (e-mail: amiruddin@ gmail.com) \\ Mahfudnurnajamuddin Indonesian \\ Indonesian Muslim University Makassar, \\ Indonesia. \\ (e-mail: mahfudnurnajamudin@yahoo.co.id) \\ Mapparenta \\ Indonesian Muslim University Makassar, \\ Indonesia. \\ (e-mail: mapparenta@umi.ac.id) \\ Zainal Arifin \\ Indonesian Muslim University Makassar, \\ Indonesia. \\ (e-mail: zainal_arifin@umi.ac.id) \\ Budiandriani \\ Indonesian Muslim University Makassar, \\ Indonesia. \\ (e-mail: budiandriani@umi.ac.id) \\ *Corresponding Author
}

\section{INTRODUCTION}

Job satisfaction is a general attitude towards a person's job, the difference between the amount of reward received by workers and the amount they believe should be received. Job satisfaction can be created if the antecedents that influence it are well accommodated and accepted by all employees in an organization [1]. The efforts made by several universities at this time are to create higher education institutions that are based on quality human resources. The real manifestation of quality human resources will be reflected in the competencies possessed by lecturers, assessment of job satisfaction, leadership, satisfaction, and performance achieved by lecturers [2]. The observation results showing that not all universities in the city of Makassar can develop lecturers' human resources into resources capable of realizing the Tridharma of Universities. Including in this case the Islamic Universities in Makassar City that still need to improve competence, motivation, and leadership to increase satisfaction and performance for lecturers. This will have an impact on the institution itself, especially in facing the challenges of globalization and the demands of organizational dynamics.

The application of competence, motivation, and leadership has always been the concern of all elements in the organization. The essence of organizational development is to develop the values of motivational competence and good organizational leadership that has been instilled by the previous founders. Competence, motivation, and leadership of lecturers at Islamic Universities in Makassar City need to be improved to avoid fragility in lecturer performance. It is still often encountered that most lecturers lack integrity in carrying out the main duties and functions assigned to them, lack of identity or identity in providing the best teaching to students, still low work responsibility in overcoming problems faced, low level of work discipline, and the ability to create a low optimal work orientation.

This phenomenon shows that the competence, motivation, and leadership of the lecturers are still fragile in influencing the satisfaction and performance of the lecturers. Due to the low competence, motivation, and leadership of lecturers in a university, lecturers often lack/do not have discipline in teaching, and low attendance, obedience, and obedience to leaders. Lecturers are obliged and take advantage of their competency abilities so that they can improve their performance in carrying out professional tasks because future education requires high-quality educational competency skills. Lecturers who have competence must meet several criteria, namely, lecturers must be committed to students and their learning process, master in-depth the course material 
they teach and how to teach students, are responsible and monitor student learning outcomes through various means of evaluation, can think systematically about what he does and learns from his experience, lecturers are part of the scientific community in their professional environment [3].

Lecturers as human resources are also required to be highly competent human resources. In substance, lecturers are professionals in the field of education. However, the phenomenon shows that among the many lecturers, there are still many who are not aware of the professionalism they have, especially those related to professional, pedagogic, social, personality, and professional competencies [4]. The number of lecturers at 7 Islamic Universities in Makassar City for 2020 is 2,485 people, with details, 543 people $(21.85 \%)$ do not have functional positions (lecturers), as many as 802 people $(32.28 \%)$ are at the Assistant professor, and 735 people $(29.58 \%)$ who have functional positions as Assistant professor, and 335 people $(13.48 \%)$ are at the level of Associate Professor, and as many as 80 people $(3,22 \%)$ as professors or professors.

This situation shows that the lecturers in Islamic Universities in Makassar City mostly have low functional positions, and some have not even obtained functional positions. The low functional position of the lecturer will affect the competence they have, which in turn will also affect the level of satisfaction and performance of the lecturer concerned.

There are still many lecturers who do not have professional competence in the fields of science, methodology, and technology applications in the areas of teaching presented; has limitations in developing social professional competence in interacting, communicating, and collaborating with fellow lecturers and students; has difficulty showing professional competence as a lecturer who has merit, wisdom, role model and self-control; professional limitations in the areas of mastery, talent, independence and discipline; and low professionalism with the professional competence it carries. Each lecturer should be required to have competence following the lecturer, the professional competency status of the lecturer they carry. Lecturer is a profession that is attached to the implementation of its main duties and functions, namely as a teaching staff.

Self-access theory [5] states that professionalism is selfaccess which shows one's competence to achieve achievement. Assessing professionalism is seen from the assessment of pedagogic, social, personality and professional abilities. This assessment is a prerequisite for someone to be said to have competent professionals, in their field. Lecturer satisfaction is also very much determined by the motivation of the lecturer at work. Motivation is something that creates enthusiasm or work motivation, so that the strong or weak work motivation of the lecturer also determines his performance, because a person's performance, especially lecturers, depends on the strength of his motive.

The motive referred to here is the desire and encouragement or movement that is in each lecturer to achieve a goal, in this case, is his performance. A person who has high motivation, will work hard, maintain the pace of hard work, and have behavior that can be controlled by himself towards important goals [6]. Thus, the high motivation of a lecturer at work will result in high performance as well.

Lecturer performance in an educational institution is an interesting factor to study because it is based on five reasons. First, the lecturer is the spearhead for the success of the teaching and learning process. Second, lecturers not only play a role in transferring knowledge to students but also provide examples of attitudes, speech, and personality behaviors. Third, the quality of lecturers is not final, but can be improved so that it always grows and develops. Fourth, the performance of lecturers should be supported by professional competence and work discipline, which can improve and improve their performance according to the expectations of individuals or institutions. Fifth, lecturers must have academic qualifications, competencies, educator certificates, are physically and mentally healthy, and have the ability to realize the goals of national education [4].

Lecturer performance is assessed from. The same thing is explained that the representation of lecturer performance is shown through the fields of education, research, community service and supporting activities [7]. A similar view explains if performance is the result of work to achieve organizational goals. Including in this case, lecturers are assessed based on results that reflect the activities of the Tridharma of Higher Education including the achievement of results in the fields of education, research, community service, and supporting activities [8].

Field facts show that if most of the lecturers at Islamic Universities in Makassar City have not fulfilled their satisfaction at work, this condition is reflected in the high complaints of lecturers mainly on complaints about opportunities or opportunities to advance the organization, besides that they are not fully allowed to excel, even in many cases. opportunities do not get recognition for work results and what is more concerning the condition of the quality of lecturers, that they think that campus bureaucratic policies in managing education are less challenging. This phenomenon is a complaint that is often conveyed by lecturers, both to their leaders and their colleagues, for the work dissatisfaction they experience. Most lecturers assume that it is difficult to carry out their duties and functions properly if the actualization of the work is felt to be unsupportive.

Based on these facts, this research was conducted to confirm the influence of work motivation, leadership, job satisfaction competencies, and lecturers' performance of Islamic Universities in Makassar City.

\section{LITERATURE REVIEW AND HYPOTHESIS}

\section{A. Competence}

Individual competence is something inherent in itself that can be used to predict the level of performance. Something that is meant can be related to motives, self-concept, nature, knowledge, and abilities/expertise. Individual competencies in the form of abilities and knowledge can be developed through education and training. Meanwhile, the competency motive can be obtained during the selection process. Consistent with this statement, competence is defined as a characteristic that underlies a person and is related to the effectiveness of individual performance in their work [9].

A similar view states that competence is a way of carrying 
out work that can be categorized as effective, efficient, productive, and quality because it has the ability that is following the conditions of the job that must be done [10]. Previous findings provide evidence that competence has a positive and significant effect on job satisfaction. Apart from being an antecedent of job satisfaction, competence is also an antecedent of individual performance [11]-[18]. The constructs used in analyzing competence include: Pedagogic competence, personality, social and professional competence.

\section{B. Motivation}

Motivation is a concept used to describe the impulses that arise in or within an individual that drives and directs behavior [19]. The theory of behavior modification (behavior modification theory) is based on the premise that a person will do an action if he gets a pleasant or pleasant stimulus and will not do an action or activity if the stimulation is painful (unpleasant). The stimulus can be known based on experience or the basis of logic whether it is pleasant or painful, even though the person has never experienced it. There are four types of behavior modification so that employees behave as desired or not desired by the leader or superior, namely: positive reinforcement; negative reinforcement; let (extinction); and punishment [20]. These four types of employee or employee behavior modification can be described as follows: [1], [21].

Work motivation is needed by an employee to be able to achieve a feeling of satisfaction at work, although according to its nature, job satisfaction itself is very relative or different from one person to another. But overall, the respondents stated that while working at the company they said they were satisfied with the work motivation that management had provided to employees. This statement is relevant to previous research that shows that work motivation has a positive and significant effect on job satisfaction [6], [11]-[13], [17], [22], [23]. Meanwhile, other findings indicate that work motivation has a negative and insignificant effect on employee performance [11], ['15], [22]. Work motivation is measured using the construct: economic needs, security, respect, social interactions, and self-actualization needs.

\section{Leadership}

Leadership is an activity to influence the behavior of others so that they want to be directed to achieve certain goals [24]. Leadership is defined as the ability to move or motivate some people to simultaneously carry out the same activities and aim at achieving their goals [25]. The important thing about leadership is the influence and effectiveness of the power of a leader. If someone wants to influence the behavior of others, then leadership activities have begun to appear relevant.

Leadership according to scholars is defined as the ability to influence others, to understand and agree on what needs to be done and how the task is carried out effectively, as well as processes to facilitate individual and collective efforts to achieve common goals [26]. Leadership is the ability to influence a group towards the achievement of a goal [1]. Leadership broadly includes the influencing process in determining organizational goals, motivating follower behavior to achieve goals, influencing to improve the group and its culture. Also, leadership influences the interpretation of the events of its followers, organizing and activities to achieve goals, maintaining cooperative relationships and group work, obtaining support and cooperation from people outside the group or organization [27].

Empirical evidence shows that leadership has a positive and significant effect on job satisfaction and employee performance [22], [23], [28]-[30]. Measurement indicators used to analyze leadership include intelligence, emotional, self-confidence, honesty, being objective, and being open.

\section{Job Satisfaction}

Job satisfaction is a set of individual feelings about pleasant or unpleasant perceptions of the organizational environment and the work performed [31]. This condition shows that job satisfaction is closely related to aspects of justice, psychological contracts between individuals and organizations, and individual motivation. The more aspects of the job that are under the wishes and expectations of the individual, the higher the level of job satisfaction that occurs in the organization. Job satisfaction is raised by the theory of human relations which can be explained by social relations where employees are related to several things of social giving which will become experiences of satisfaction and feel an obligation to help each other, as a form of increased productivity.

Employee satisfaction and attitudes are important factors in determining behavior and responses at work, and this is evidence that organizational effectiveness can be achieved [32]. It can be explained that the understanding of job satisfaction has broad aspects, job satisfaction can not only be understood from the physical aspects of the job itself but the non-physical side.

Job satisfaction is related to the physical in carrying out his job duties, the conditions of his work environment, it is also related to his interactions with colleagues and the system of relationships between them. Besides, job satisfaction is also related to job prospects, whether it provides hope for development or not. The more aspects of the expectations are met, the higher the level of job satisfaction. The level of job satisfaction can be seen from several aspects such as the level of productivity, the level of absenteeism, and the level of resignation from work.

Empirical facts show that job satisfaction has a positive and significant effect on individual performance [2], [6], [29], [33]-[38]. Instruments of job satisfaction are used as a measure, namely responsibility, progress, achievement, recognition, and the work itself.

\section{E. Lecturer Performance}

Performance is an achievement of certain job requirements which ultimately can be reflected in the output produced [39]. Performance is a reflection of actual performance (actual work performance or achievement achieved by a person). The definition of performance (work performance) is the result of work in quality and quantity achieved by an employee in carrying out his duties following the responsibilities given to him [40]. Another scholar's view explains performance as a set of results achieved and refers to the achievement and implementation of a job requested and performance is a function of motivation and ability [19].

Conditions that must be known and informed to certain parties to determine the level of achievement of an organization's results related to the vision and mission carried out by an organization and to know the positive and negative 
impacts of predetermined operational policies are a representation of the performance used by management to conduct periodic assessments of the operational effectiveness of an organization, the effectiveness of employees based on their main duties and functions and based on predetermined standards that function as a means of controlling the success of the organization [41]-[43]. Measurement of lecturer performance used includes in the fields of education, research, community service, and supporting activities.

\section{RESEARCH METHODS}

This research is based on explanatory research which explains the position of the variables under study and the relationship between one variable and another. The sample used was 327 permanent lecturers at Islamic Universities in Makassar City, both Foundation Lecturers and civil servants Lecturers (DPK). The structural equation model analysis tool (AMOS) is used in analyzing the data.

\section{RESULTS}

TABLE I: RESPONDENTS

\begin{tabular}{|c|c|}
\hline Characteristics & Percentage \\
\hline \multicolumn{2}{|l|}{ Gender } \\
\hline Male & 61.50 \\
\hline Female & 38.50 \\
\hline \multicolumn{2}{|l|}{ Ages } \\
\hline$\leq 30$ years & 0.92 \\
\hline $31-40$ years & 33.03 \\
\hline $41-50$ years & 27.52 \\
\hline 51 years & $38.53>$ \\
\hline \multicolumn{2}{|l|}{ Group on occupation } \\
\hline III & 53.80 \\
\hline IV & 46.20 \\
\hline \multicolumn{2}{|c|}{ Recognition (Certification) } \\
\hline Not certified & 34.90 \\
\hline Certified & 65.10 \\
\hline \multicolumn{2}{|l|}{ Work experience } \\
\hline$\leq 10$ years & 3303 \\
\hline $10,1-20$ years & 29.05 \\
\hline $20,1-30$ years & 34.56 \\
\hline$>30.1$ years & 3.37 \\
\hline \multicolumn{2}{|l|}{ Educational level } \\
\hline Masters & 65.10 \\
\hline Doctoral & 34.90 \\
\hline
\end{tabular}

The majority of respondents are men at the age level $>51$ years and if based on the level of work class, then generally they are at level III and have obtained recognition from the State in the form of lecturer certification, based on tenure, they have predominantly worked for 20.1-30 years with the final level of master's education.

TABLE II: VARIABLE DESCRIPTION

\begin{tabular}{cccc}
\hline \multicolumn{4}{c}{ TABLE II: VARIABLE DESCRIPTION } \\
\hline Variables & Mean & $\begin{array}{c}\text { Validity test } \mathrm{p} \\
<0.05\end{array}$ & $\begin{array}{c}\text { Cronbach's } \\
\text { Alpha }\end{array}$ \\
\hline Competence & 3.38 & $0.90-0.91$ & 0.89 \\
Work motivation & 3.43 & $0.75-0.87$ & 0.88 \\
Leadership & 3.68 & $0.79-0,83$ & 0.88 \\
Job satisfaction & 3.52 & $0.66-0.85$ & 0.81 \\
Performance & 3.24 & $0.77-0.78$ & 0.81 \\
\hline
\end{tabular}

The mean value of the variable is in the interval from 3.24 to 3.68 with the highest Leadership value, the whole construct is stated to have a validity level of $0.66-0.91$ with a reliability value of $>0.80$.
Assumption testing, first, Outliers Test. The results showed that there were several variables or research indicators that were outliers, the distance between Mahalanobis and the centroid was significant $(\mathrm{p}<0.05)$. However, descriptively based on the mean and standard deviation values, it is found that all research indicators have a mean value that is greater than the standard deviation so that all indicators do not contain outlier's data. Second, Normality Data. The results of checking the data normality assumption show that multivariate data are not normally distributed ( $\mathrm{cr}=39.070$, while the critical value of $\mathrm{Z}$ at $\mathrm{a}=0.05$ is 1.96 ). However, this assumption is not critical when the sample size is large. Final test, Linearity. The test results show that what is used in this study is linear, so it can be analyzed further.

\section{A. Goodness of Fit Model}

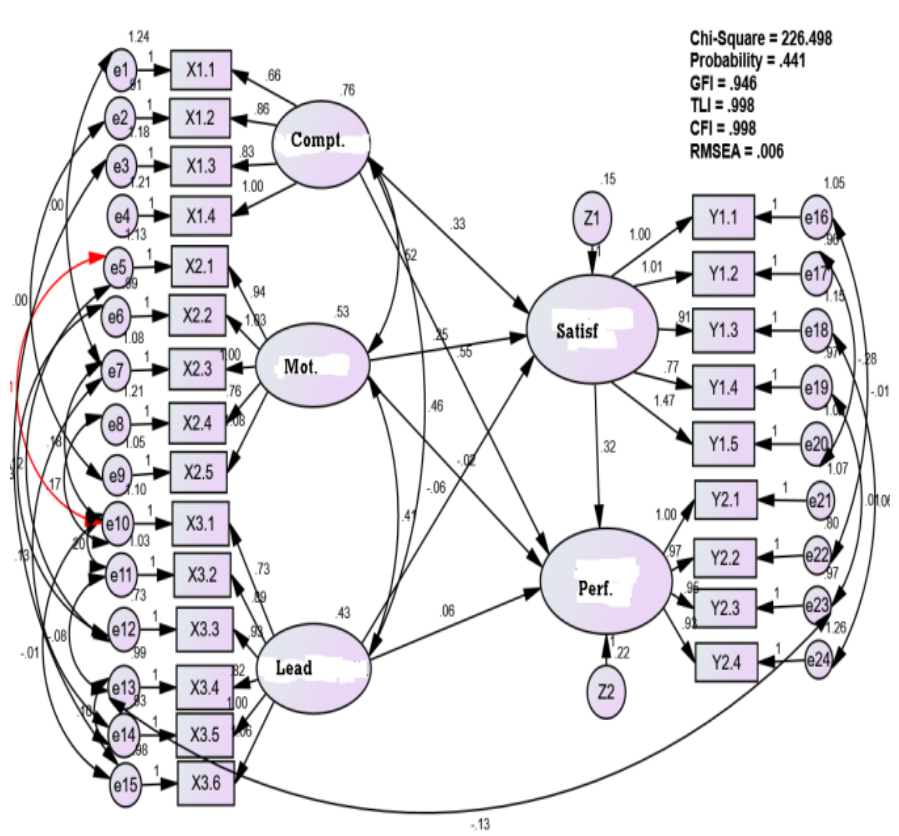

Fig. 1. Goodness of Fit.

The conclusive explanation can be shown in the following table.

\begin{tabular}{ccc}
\multicolumn{3}{c}{ TABLE III: GOODNESS OF FIT OVERALL } \\
\hline GOF & Results & Cut-off \\
\hline Chi-square & 226,498 & Small \\
Probability & 0,441 & $\geq 0,05$ \\
RMSEA & 0,006 & $\leq 0,08$ \\
GFI & 0,946 & $\geq 0,90$ \\
AGFI & 0,928 & $\geq 0,90$ \\
TLI & 0,998 & $\geq 0,95$ \\
CFI & 0,998 & $\geq 0,95$ \\
CMIN/DF & 1,011 & $\leq 2,00$ \\
\hline
\end{tabular}

The p-value $0.441>0.05$ indicates that the null hypothesis which states there is no difference between the sample covariance matrix and the estimated population covariance matrix is acceptable. Acceptance of the null hypothesis provides meaning if there is no difference between the sample covariance matrix and the estimated population covariance matrix, so the model is feasible to use. Other indices (CMIN / DF, GFI, AGFI, TLI, CFI, and RMSEA) also show the level of acceptance of the model.

TABLE IV: CONFIRMATORY FACTOR ANALYSIS (P <0.05) 


\begin{tabular}{ccc}
\hline Construct & Loading Factor & Critical Ratio \\
\hline Competency & $0.60-1.00$ & $6.78-8.46$ \\
Motivation & $0.76-1.00$ & $6.58-8.20$ \\
Leadership & $0.72-1.00$ & $5.74-7.40$ \\
Satisfaction & $0.76-1.47$ & $5.22-6.31$ \\
Performance & $0.92-1.00$ & $8.10-8.78$ \\
\hline
\end{tabular}

Confirmatory factor analysis shows that the overall construction can be used as a measure of the variables being analyzed.

TABLE V: EXOGENOUS EFFECT

\begin{tabular}{ccccc}
\hline Causality & Direct & Indirect & Total & p-value \\
\hline Compt $\rightarrow$ Satisf & 0,50 & 0,00 & 0,50 & $0,00<0.05$ \\
Mot $\rightarrow$ Satisf & 0,32 & 0,00 & 0,32 & $0,02<0.05$ \\
Lead $\rightarrow$ Satisf & $-0,07$ & 0,00 & $-0,07$ & $0,09>0.05$ \\
Compt $\rightarrow$ Perf & 0,59 & 0,00 & 0,59 & $0,00<0.05$ \\
Mot $\rightarrow$ Perf & $-0,01$ & 0,00 & $-0,01$ & $0,06>0.05$ \\
Lead $\rightarrow$ Perf & 0,05 & 0,00 & 0,05 & $0,04<0.05$ \\
Satisf $\rightarrow$ Perf & 0,22 & 0,00 & 0,22 & $0,01<0.05$ \\
Compt $\rightarrow$ Satisf $\rightarrow$ Perf & 0,50 & 0,20 & 0,71 & $0,01<0.05$ \\
Mot $\rightarrow$ Satisf $\rightarrow$ Perf & 0,32 & $-0,26$ & 0,05 & $0,25>0.05$ \\
Lead $\rightarrow$ Satisf $\rightarrow$ Perf & $-0,07$ & 0,10 & 0,03 & $0,16>0.05$ \\
\hline
\end{tabular}

\section{B. Contribution of Competence to Job Satisfaction}

Competence has a positive and significant effect on the work motivation of lecturers at Islamic Universities in Makassar City. The regression coefficient value which is positive is 0.507 and the $p$-value is $0.008<0.05$. This situation shows that the competence of lecturers of Islamic Higher Education in Makassar City has contributed to creating job satisfaction for them. Job satisfaction is created because lecturers are responsible for carrying out teaching as an obligation given by the college, lecturers feel satisfied with their work because of the progress made by students in the learning process, Feelings of satisfaction with the achievements achieved by students in the courses they teach, recognition that they have manifested high credibility in carrying out their duties. This condition occurs because of the responsibility for the work they have been doing with all their hearts. This study confirms the findings of previous researchers that competence is proven to be an antecedent of job satisfaction [11]-[18].

\section{Contribution of Work Motivation to Job Satisfaction}

Work motivation has a positive and significant effect on job satisfaction felt by lecturers. This statement is shown by the coefficient value which is a positive sign 0.032 with a pvalue of $0.02<0.05$. These findings are relevant to the field facts that lecturers have high work motivation to carry out their duties and obligations as lecturers. Respondents' responses indicate the fulfillment of economic needs, fulfillment of security needs, need for appreciation, need for social interaction, the need for self-actualization so that they feel satisfaction at work because of the fulfillment of economic needs, security, and appreciation as well as the establishment of good social interactions which then become the lever of actualization. themselves. These results are relevant to the empirical fact that increased work motivation has a real impact on job satisfaction [6], [11]-[13],[17], [22], [23].

\section{Contribution of Leadership to Job Satisfaction}

The results of the analysis show that the negative regression coefficient is -0.072 with a p-value of $0.096>0.05$, that leadership has a negative and insignificant effect on employee job satisfaction. These results reject the hypothesis that leadership has a positive and significant effect on employee job satisfaction. This situation shows that the leadership shown cannot increase the job satisfaction of the lecturers, especially in terms of satisfaction with responsibility, progress, achievement, recognition of credibility, and commemorating the work itself. This is caused by; some of the lecturers have a limited level of intelligence in carrying out knowledge transformation, lecturers have limitations in maintaining their emotional stability as evidenced by the relatively low self-confidence in dealing with all problems, lecturers who have limited integrity when in a campus environment, are less objective in providing an assessment of student activities in the learning process, and the low desire of lecturers to be open to students so that students lack trust and respect for him. The findings of this study reject some previous research, that leadership has a positive and significant effect on job satisfaction and employee performance [22], [23], [28]-[30].

\section{E. Competence Contribution to Performance}

The regression coefficient of the influence of competence on performance shows a positive sign of 0.598 and a p-value of $0.00<0.05$. These results indicate acceptance of the hypothesis that competence has a positive and significant effect on job satisfaction. This fact proves that the competence possessed by lecturers makes a significant contribution to the achievement of performance which is shown by the ability to carry out tri dharma tertiary activities. This fact can be shown by the high mastery of pedagogic competence so that lecturers can manage students, lecturers have good personal and social, and professional competencies so that it has a real impact on the creation and achievement of the results of good work implementation. These results confirm previous research, that competence is an antecedent of performance [11]-[18].

\section{F. Work Motivation Contribution to Performance}

The results showed the rejection of the hypothesis, the coefficient value is negative 0.014 with a p-value of $0.063>0.05$. This means that work motivation has not been able to improve lecturer performance. This condition is caused because some of the lecturers have not met their needs, such as economic needs, security, respect, social interaction, and the need for self-actualization. The statement explains that motivation as a stimulus for lecturers in carrying out their duties and responsibilities has an impact on the low performance of the lecturers in carrying out the learning process, community service, and other supporting activities. The results of this research are relevant to previous findings that work motivation has a negative and insignificant effect on employee performance [11], [15], [22].

\section{G. Leadership Contribution to Performance}

The data analysis conducted showed acceptance of the hypothesis, as evidenced by the positive regression coefficient value 0.051 and $p$-value $0.046<0.05$. These results explain that the better the leadership shown in Islamic tertiary institutions in Makassar City, the higher the performance produced by the lecturers. This condition can be shown by the 
lecturer having a professional level of intelligence, the lecturer can handle their emotions so that this attitude proves to be the driving force for the creation of a high performance. This finding is relevant to the results of previous research that the resulting high performance is due to the good quality of leadership shown [22], [23], [28]-[30].

\section{H. Contribution of Job Satisfaction to Performance}

The results show that job satisfaction has a positive and significant effect on lecturer performance. This is evidenced by the value of the regression coefficient which is positive, which is 0.227 and the probability value is $0.012<5 \%$. The results of this study are in line with the hypothesis so that the research hypothesis is accepted. This situation shows that the better the level of job satisfaction of the lecturers, the better the performance of the lecturers will be. The results of this study have implications, that in general, lecturers have been satisfied with the responsibility in teaching as a mandate given, the emergence of a feeling of satisfaction from the lecturers with the progress made by students in the learning process, towards the achievements achieved by students in the course. they teach, and to the recognition that they have manifested high credibility in carrying out their duties and enjoy their work which they have been devoted to so far with all their hearts. These results confirm previous findings, that job satisfaction has a positive and significant effect on individual performance [2], [6], [29], [33]-[38].

\section{Indirect Contribution: Competence, Work Motivation, and Leadership on Performance through Job Satisfaction}

The performance of lecturers at Islamic Universities in Makassar City is determined by competence, work motivation, and leadership. Competence indirectly has a positive and significant effect on lecturer performance through job satisfaction, as evidenced by the indirect effect value of 0.207 and a significance value of 0.017 . This can be explained that lecturer performance will increase if it is mediated by job satisfaction, or directly without being mediated by job satisfaction. Competence will be able to improve the performance of lecturers after they are given work motivation because most of these lecturers have high competence, both pedagogical competence and personal competence, social, and professional competence. Indirectly, work motivation has a negative and insignificant effect on lecturer performance through job satisfaction. This is evidenced by the negative value of the regression coefficient of 0.262 and a significance value of 0.256 . This means that work motivation directly or indirectly has a negative and insignificant effect on improving lecturer performance.

The same thing applies to leadership, which has a positive and insignificant effect on lecturer performance through job satisfaction. This is evidenced by the value of the regression coefficient of 0.107 and a significance value of 0.161 . This shows that, directly or indirectly, leadership will influence on improving the performance of lecturers at the Islamic Universities in Makassar City, although it is not significant. Taking into account the research results and descriptions previously stated, it can be explained that; competence has a positive and significant effect on lecturer performance through job satisfaction, work motivation has a negative and insignificant effect on lecturer performance through job satisfaction, and leadership positive and insignificant effect on lecturer performance through job satisfaction.

\section{CONCLUSION}

The results of this study provide evidence that leadership has a negative and insignificant effect directly on job satisfaction. Direct motivation has a negative and insignificant effect on lecturer performance, and indirect motivation has a negative and insignificant effect on lecturer performance through job satisfaction at Islamic Universities in Makassar City. The better of the leadership that is displayed has a real impact on the job satisfaction felt by the lecturers. The leadership shown in Islamic tertiary institutions in Makassar City has not fully provided job satisfaction to the lecturers. This is because some individual lecturers have a level of intelligence that has not been optimal in transferring their knowledge and knowledge, then they tend not to be optimal in controlling their emotions in carrying out their assignments. This condition is relevant to their low selfconfidence and low level of honesty in carrying out tasks so that it has an impact on low objectivity in giving assessments and being closed so that their students give low respect and even do not trust them as lecturers.

The higher a person's motivation to work has a real impact on the resulting increase in performance. The findings of this study provide different results that directly or indirectly, work motivation has a negative and insignificant effect on lecturer performance. This fact shows that some of the lecturers are still lacking and even unable to generate high work motivation because their economic needs have not been fully met, as well as economic needs, security, respect, social interaction, and self-actualization. This study provides recommendations to the campus management to improve competence and work motivation, as well as improve leadership for each lecturer. by providing opportunities for lecturers to take part in education and training by their fields of expertise. Increasing the motivation of lecturers to work can be done by fulfilling economic needs, a sense of security, appreciation, social interaction, and creating selfactualization of lecturers. It takes serious efforts from the campus bureaucracy to improve emotional intelligence, increase self-confidence, honesty, be open and objective.

\section{REFERENCES}

[1] Robbins, S, P, (2012). Organizational Behavior Concept, Controversies, Applications, 9 Ed. Prentice Hall, Inc. Eaglewood, Cliff, New Jersey.

[2] Toban, C., \& Sjahruddin, H. (2016). The antecedent and consequence of Organizational Commitment and Job Satisfaction. Journal of Business and Management Sciences, 4 (2), 26-33.

[3] Sumartiningsih, Maria Susila. (2015). The Influence of Professional Competence and Organizational Climate on Lecturer Performance (Case Study at Budi Luhur Academy of Nursing and Ahmad Yani Cimahi). Thesis. Postgraduate Program - UPI. Not Published.

[4] Government of the Republic of Indonesia. (2005) Law of the Republic of Indonesia Number 14 of 2005 concerning Teachers and Lecturers. State Gazette of the Republic of Indonesia.

[5] Walcott, G., \& Hickling, FW (2013). Correlates of conflict, power and authority management, aggression, and impulse control in the Jamaican population. West Indian Medical Journal, 62 (5).

[6] Winardi, Jasman, \& Said, Musnadi. (2016). The Influence of Organizational Culture and Motivation on Employee Performance with 
Job Satisfaction as an Intervening Variable (Study at the Aceh Provincial Irrigation Service). Journal of Management Science, Graduate School of Syiah Kuala University, Volume 1 (1), May 2016: $1-24$.

[7] Government of the Republic of Indonesia. Law of the Republic of Indonesia regarding the National Education System, Number 20 of 2002, State Gazette of the Republic of Indonesia.

[8] Nelson, Neil. (2014). Human Resource Management In Strength Quality Prospective. Published McGraw Hill, New York.

[9] Mitriani, Alain. (2015). Human Resource Management Based on Competence. Translation of Pustaka Utama Grafiti, Jakarta.

[10] Steers, RM \& LW, Porter, (2005). Motivation and Work Behavior. Academic Press, New York.

[11] Harrison, Rosemary. (2011) Analysis of Culture Organization, Competence Motivation toward, Commitment to Increasing the Performance of Employee in Florida Government. Administration Science Science Quarterly June. 91-96.

[12] Akram Zaki. (2014). The Influence of Motivation, Work Facilities, and Competence on Organizational Commitment and Employee Performance at the Transportation Agency in South Sumatra Province. Journal of Business and Economics (JBE), Vol. 18, No. 1. 170-187.

[13] Thorlakson, Alan JH \& Robert, P. Murray, (2014). An Empirical Study of Empowerment in the Workplace, Journal Group \& Organization Management, Vol. 21 (1). 67-83.

[14] Rian, Andriani. (2014). The Influence of Organizational Culture and Competence on Employee Satisfaction at the State Savings Bank in Bandung. Journal of Ecodemica: Economics, Management and Business, Bina Sarana Informasi University, Vol. 2 (2).

[15] Kartini. (2015). The Influence of Competence, Organizational Commitment, and Organizational Culture on Job Satisfaction and Employee Performance at the Regional Secretariat of East Kutai Regency. Paradigm Journal, Vol. 4. (1).

[16] Samiun, B., Sjahruddin, H., \& Purnomo, SH (2017). The Effect of Empowerment on Employee Job Satisfaction. Journal of Organization and Management. Vol. 2 (1). 28 -37

[17] Deswarta. (2017). The Influence of Competence and Motivation on Job Satisfaction and Lecturer Performance at the Faculty of Tarbiyah and Teacher Training, UIN Suska Riau. Journal of Currency Vol. 3 (1).

[18] Solehudin \& Abdul Yusuf. (2018). The Influence of Organizational Culture and Competence on Job Satisfaction at PT. Harmonious Mitra Sejahtera. Journal of Value, Journal of Management and Business, Vol. $3,(1)$.

[19] Gibson, James L, Ivancevich, John M \& Donnely, James, (2014). Organizational Behavior, Structure, Process. $3^{\text {rd, }}$ Edt., Business Publications, Inc., Dallas.

[20] Siagian, Sondang P., (2012). Human Resource Management. Earth Literacy. Jakarta.

[21] Gibson, L. James, Ivancevich, M. John, \& Donnely, H. James, (2017). The organization, Process Structure Behavior, Volume 1, Fifth Edition, Translation, Jakarta: Erlangga.

[22] Fatima Bushra, Ahmad Usman, \& Asvir Naveed. (2015). Effect of Transformational Leadership and Motivation on Employees Job Satisfaction and Performance in the Banking Sector of Pakistan. International Journal of Business and Social Science, Vol. 2, N0. 18, October 2011, pp. 161-167.

[23] Ida Ayu Brahmasari \& Agus Suprayetno, (2016). Effect of Work Motivation, Leadership, and Organizational Culture on Employee Job Satisfaction and its Impact on Employee Performance at PT. Pei Hai International Wiratama Indonesia, Journal of Management and Entrepreneurship, Vol. 10, (2). 124-135.

[24] Miftah, Thoha. (2014). Leadership in Management, A Behavioral Approach, Rajawali Press, Jakarta.

[25] Nawawi, Hadari, (2012). Human Resource Management For Competitive Business. Gadjah Mada University Press. Yogyakarta.

[26] Yukl, Gary. (2015). Leadership in Organizational, Fifth Edition, New Jersey: Prentice-Hall. Upper Saddle River, 07458.

[27] Veithzal Rivai \& Ahmad Fawzi Mohd Basri. (2008). Performance Appraisal The Right System To Assess Employee Performance And Improve Company Competitiveness. PT. Raja Grafindo Persada, Jakarta.

[28] Yafang, Tsai. (2011). The Influence of Organizational Culture and Leadership Behavior on Job Satisfaction. Tsai BMC Health Services Research, Department of Health Policy and Management, Chung Shan Medical University, Taiwan, 1-9.

[29] Peter Lok, \& John Crawford. (2014). The Effect of Organizational Culture and Leadership Style on Job Satisfaction and Organizational Commitment, Journal of Management Development, Vo. 23. No. 4, 321-338.

[30] Sunadji, Eka Afnan, Surachman, \& Armanu. (2015). The Role of Organizational Culture, Leadership, Communication on Job
Satisfaction (Study on Public Enterprise of Water Resources Management of Ministry State Owned Enterprise). International Journal of Business and Behavioral Sciences. Vol. 3,. (2), 34-42.

[31] Barney \& Griffin, (2014). Human Resource Management. Published by McGraw Hill, Ohio.

[32] Ostroff, C. (2012). The relationship between satisfaction, attitudes, and performance: Organizational Level Analysis. Journal of Applied Psychology, 77, 963-974.

[33] Alamdar Hussain Khan, Muhammad Musarrat Nawas, Muhammad Aleem, \& Wasim Hamed. (2012). Impact of Job Satisfaction on Employee Performance: An Empirical Study of Autonomous Medical Institutions of Pakistan. Frikan Journal of Business Management, Volume 6 (7), 2697-2705.

[34] Gae-Liang Wang, Yu-Je Lee, \& Chuan-Chih Ho. (2017). The Effects of Job Satisfaction, and Competence on Employee Performance: As Exemplified with Employees of Listed Property Insurance Companies in Taiwan. Research in Business and Management, Volume 1 (2), 41 53.

[35] Sarminah Samad. (2013). The Effects of Organization Commitment on Job Satisfaction and Job Performance Relationship: A Case of Managers in Malaysia's Manufacturing Companies. European Journal of Social Sciences, Volume 18, (4) 602-611.

[36] Morad Rezaei Dizgah, Mehrdad Goodarzvand Chegini, \& Roghayeh Bisokhan. (2015). The Effects of Job Satisfaction on Employee Performance in the Guilan Public Sector. Journal of Basic and Applied Scientific Research, Iran: 1735-1741.

[37] Ehsan Malik. (2016). Job Satisfaction and Organizational Commitment of University Teachers in the Public Sector of Pakistan. International Journal of Business and Management, Vol. 5, (6), 17-26.

[38] Chamdan Purnama. 2016. Influence Analysis Organization Culture, and Job Satisfaction on Employee Performance. International Journal of Business, Humanities, and Technology. Vol. 3, (5), 86-100.

[39] Simamora, Henry. (2012). Human Resource Management, Second Edition, STIE YKPN, Yogyakarta.

[40] Mangkunegara. (2014). Strategic Human Resource Management, Ghalia Indonesia, Jakarta.

[41] Gomes, Faustino Cardoso. (2016). Human Resource Management, Andi Offset, Yogyakarta.

[42] Hasanuddin, R., \& Sjahruddin, H. (2017). The structure of emotional intelligence, spiritual intelligence, and its relationship with work enthusiasm and auditor performance. Structure, 3 (1), 67-85.

[43] Nur, IG, \& Sjahruddin, H. (2019). The Influence of Transformational Leadership and Work Motivation on Employee Performance. Journal of Organization and Management. Vol. 2 (1). 38 - 46. 